\title{
Rola Indii w Organizacji Narodów Zjednoczonych według koncepcji politycznej Jawaharlala Nehru
}

Aktywność dyplomacji indyjskiej rozwijana na forum Organizacji Narodów Zjednoczonych na przełomie lat pięćdziesiątych i sześćdziesiątych odzwierciedla w pełni zarys ideologiczny światopoglądu Jawaharlala Nehru ${ }^{1}$. Inferencja tej problematyki ukazuje szeroki wachlarz zagadnień polityki zagranicznej Indii od ogólnie rozumianego ładu międzynarodowego aż po prawa człowieka. Utrwalony w powojennym świecie uniwersalny w swoim charakterze „system oenzetowski” odpowiadał wizji porządku światowego Nehru. Jak stwierdzał w jednym ze swych licznych przemówień: „Jednym z atrybutów ONZ jest uniwersalizm. Inne cele to utrzymanie pokoju, intensyfikacja współpracy między narodami i rozwiązywanie sporów pokojową metodą tak długo, jak to jest to możliwe"².

Przywódca Indii — zdeklarowany zwolennik współpracy międzynarodowej opartej na zasadzie federalizmu - jeszcze w latach trzydziestych XX w. głosił konieczność powołania organizacji ogólnoazjatyckiej opartej na wzorcach amerykańskich. W obliczu fiaska tej koncepcji nadzieja na odbudowanie solidarności międzynarodowej odrodziła się wraz z powstaniem $\mathrm{ONZ}^{3}$. Nową erę w polityce zagranicznej Indii zainicjowano 30 X $1945 \mathrm{r}$. Jeszcze przed uzyskaniem pełni suwerenności Indie przystąpiły formalnie do ONZ. Indyjska delegacja na konferencji w San Francisco ${ }^{4}$ aktywnie uczestniczyła w dyskusji dotyczącej kształtu i charak-

\footnotetext{
${ }^{1}$ Jawaharlal Nehru (1889-1964), indyjski mąż stanu, jeden z głównych przywódców Indyjskiego Kongresu Narodowego, najbliższy współpracownik M. Gandhiego. Premier Indii w latach 1947-1964. Architekt polityki zagranicznej i wewnętrznej Indii. Ojciec ideologiczny Ruchu Państw Niezaangażowanych, zwolennik solidarności afroazjatyckiej. M. Brecher, Nehru, a Political Biography, London 1959; S. Gopal, Jawaharlal Nehru, New Delhi 1984; B. Mrozek, Nehru, Warszawa 1974.

${ }^{2}$ Przemowa Nehru w Parlamencie New Delhi, 12 VI 1952. J. Nehru's Speeches (1949-1953), New Delhi 1954, s. 222, 223.

${ }^{3} \mathrm{~W}$ przeciwieństwie do takich organizacji Pakt Warszawski, NATO, SEATO i Pakt Bagdadzki miały — zdaniem Nehru — promować klimat wrogości i strachu.

${ }^{4}$ W skład delegacji indyjskiej na konferencji w San Francisco w 1945 r. wchodzili: sir C. P. Ramaswamy Mudaliar, Firoz Khan Noon i V. T. Krishnamachari. H.M. Verma, India and World Affairs. Foreing Policy of India, New Delhi 1984, s. 161.
} 
teru Karty ONZ, stanowiącej literę prawa przyszłej organizacji międzynarodowej ${ }^{5}$. Niezależny już rząd indyjski w dniu ogłoszenia niepodległości 15 VIII 1947 r. zadeklarował aktywną rolę Indii na forum nowo powstałej organizacji. Deklaracje te podtrzymywane były w późniejszych wystąpieniach Nehru, który pełen optymizmu i nadziei wypowiadał się o obecności Indii w tym międzynarodowym systemie: „Współdziałamy w tworzeniu ONZ. Nasz udział nie odbiera nam niezależności. Oczywiście ogranicza naszą wolność w tym sensie, jak ograniczana jest wolność wszystkich jej członków. Jest to naturalną konsekwencją przynależności do każdej organizacji. [...] Wyjść z ONZ czy pozostać w ONZ? My pozostaniemy, gdyż czujemy, że taka światowa organizacja jest bardzo potrzebna. Liga Narodów upadła, ONZ wydaje się sprawną instytucją, zaś Karta ONZ jest bardzo potrzebnym dokumentem"6.

Przywódca Indii, inicjując obecność swojego kraju na forum Zgromadzenia Ogólnego ONZ, kierował się trzema zasadniczymi aspektami:

1. Uaktywnienia dyplomacji indyjskiej na rzecz przyspieszenia procesu dekolonizacji.

2. Działalności na rzecz pokojowego rozwiązywania sporów międzynarodowych i łagodzenia lokalnych konfliktów między członkami ONZ, w tym poprzez osobisty udział w mediacjach i koncyliacjach.

3. Propagowania koncepcji rozbrojenia i kontroli zbrojeń ${ }^{7}$.

Lansowana przez rząd indyjski polityka antykolonialna omawiana była wielokrotnie na forum ONZ. Określała ona nie tylko działania na rzecz przyspieszenia procesu dekolonizacji, ale również wszelkie wysiłki zapobiegające odrodzeniu starych kolonialnych wpływów określane przez Nehru „neokolonializmem”. Równocześnie zapewniał on, że ,antykolonialna krucjata" nie musi prowadzić do sporów między bogatą Północą a biednym Południem naszego globu. Uczestnicząc w pracach ONZ, Indie wielokrotnie uzewnętrzniały swoje sympatie dla ruchu narodowowyzwoleńczego krajów kolonialnych, między innymi poprzez energiczną działalność i zaangażowanie na rzecz rozwiązania kryzysu w Indonezji ${ }^{8}$. Przedstawiciele Indii uczestniczyli w rozmowach prowadzonych na rzecz niepodległości Maroka i Tunezji, a także w debacie o portugalskiej dominacji w Afryce ${ }^{9}$. Współtworzono ogólną deklarację o popieraniu wszelkich dążeń niepodległościowych w Afryce, a także propagowano ideę walki z rasizmem ${ }^{10}$. Indie głosiły politykę antykolonializmu na wszystkich płaszczyznach wy-

\footnotetext{
${ }^{5}$ Indyjskie propozycje odnosiły się do sposobu wyboru niestałych członków Rady Bezpieczeństwa ONZ. Indie optowały, by Rada Bezpieczeństwa raczej mianowała, niż wybierała siedmiu niestałych członków. Ze względu na możliwość uzyskania w przyszłości statusu stałego członkowstwa wybór ten powinien być rozsądny i uzasadniony, a państwa wchodzące do Rady Bezpieczeństwa muszą spełniać określone kryteria, takie jak: czynnik demograficzny, stabilny rozwój ekonomiczny, wysoki stopień uprzemysłowienia, silna armia itp. Indyjska delegacja wysunęła propozycję, by Zgromadzenie Ogólne obok siedmiu niestałych członków wyznaczyło dodatkowo siedem państw, które w charakterze obserwatorów mogłyby uczestniczyć w dyskusji w Radzie Bezpieczeństwa bez prawa głosu. W toczącej się debacie wokół kształtu i funkcjonowania Rady Bezpieczeństwa strona indyjska była jeszcze przeciwna zasadzie weta w Radzie Bezpieczeństwa. Na skutek rywalizacji zimnowojennej Indie zmieniły zdanie w tej kwestii. A. Sinha, M. Mohta, Indian Foreign Policy. Challenges and Opportunities, New Delhi 2007, s. 194.

${ }^{6}$ Przemowa Nehru w Parlamencie New Delhi, 12 VI 1952. J. Nehru's Speeches (1949-1953), s. 222, 223.

${ }^{7}$ A. P. Rana, The Imperatives of Nonalignment. A Conceptual Study of India's Foreign Policy Strategy in the Nehru Period, New Delhi 1976, s. 226.

${ }^{8}$ Ibidem, s. 228.

${ }^{9}$ Ibidem.

${ }^{10}$ I. Lazari-Pawłowska, Nehru, Warszawa 1991, s. 269.
} 
miany poglądów — zwłaszcza w Zgromadzeniu Ogólnym i Radzie Bezpieczeństwa. Należy jednak podkreślić, że zaangażowanie rządu indyjskiego w utworzenie Wspólnoty Narodów

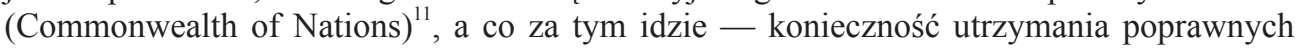
relacji z Wielką Brytanią czyniło radykalny w swych hasłach program antykolonialny szczególnie w początkowej jego odsłonie — dość niewygodnym. Po 1956 r., a zwłaszcza w obliczu konfliktu sueskiego, Nowe Delhi było bardziej zdeterminowane w realizacji swych celów. Nehru zaczął wówczas dochodzić do wniosku, że należy pogodzić się z faktem istnienia zasadniczych różnic między państwami rozwiniętymi a rozwijającymi się, co zasygnalizował w wystąpieniu na konferencji Ruchu Państw Niezaangażowanych w Belgradzie ${ }^{12}$.

Jak podkreślają badacze problematyki, istotniejszym niż antykolonializm powodem zaangażowania Indii na forum ONZ było przekonanie Nehru, że w okresie zimnej wojny organizacja ta stanowi gwarancję bezpieczeństwa i stwarza możliwość egzystencji politycznej słabszym państwom ${ }^{13}$. Ponadto dość wyraźnie dało się zauważyć, że z jednej strony Indie dość pobłażliwie podchodziły do sowieckiej dominacji w krajach Europy Środkowo-Wschodniej, z drugiej zaś wszczynały — pod hasłem walki z neokolonializmem — głośną krytykę poczynań Zachodu. Indyjczycy nie mogli dopuścić do tego, by dawne zachodnie potęgi kolonialne nadal utrzymywały kontrolę nad słabymi jeszcze „wyzwoleńcami”. Takie stanowisko thumaczy krytykę powołania do życia Paktu Północnoatlantyckiego, zwłaszcza przystąpienia do sojuszu Portugali i Holandii. Rząd indyjski fakt ten utożsamiał przede wszystkim ze zjawiskiem odradzania się neokolonializmu, oskarżając NATO o tolerowanie i wspieranie polityki umacniania wpływów poszczególnych państw członkowskich w dawnych posiadłościach kolonialnych ${ }^{14}$.

Dyplomacja indyjska podejmowała się na forum ONZ mediacji w obliczu licznych kryzysów międzynarodowych. Warto wspomnieć zaangażowanie w rozwiązanie konfliktów w Azerbejdżanie, Indonezji, Korei, Indochinach, Libanie, Kongu czy w wojnie arabskoizraelskiej. W sprawie algierskiej Indie proponowały negocjacje z Francuzami na zasadzie de iure, aż do odzyskania całkowitej niezależności. Podobnego wsparcia udzielano narodom afrykańskim w ich walce z przejawami rasizmu i segregacji rasowej ${ }^{15}$. W tych wszystkich przypadkach, a zwłaszcza w kontekście wydarzeń w Kaszmirze, Indie od połowy lat pięćdziesiątych utożsamiały rywalizację zimnowojenną ze zjawiskiem neokolonializmu ${ }^{16}$.

Republika Indii, będąc państwem współtworzącym oenzetowski system bezpieczeństwa globalnego, odgrywała istotną rolę w propagowaniu idei operacji pokojowych (Peace Keeping Operations of UN) - jedynej wówczas możliwej formy zapewnienia stabilizacji na arenie międzynarodowej. Akceptując ten model rozwiązywania konfliktów pod auspicjami ONZ, Nehru kierował się zarówno potrzebą powstrzymania konfliktów i im przeciwdziałania, jak też dążeniem do utworzenia międzynarodowych sił militarnych, będących buforem

\footnotetext{
${ }^{11}$ Wspólnota Narodów (nazwa od 1949 r.) — zinstytucjonalizowana forma współpracy państw dawnego imperium brytyjskiego, wprowadzona w miejsce Brytyjskiej Wspólnoty Narodów. Obecnie Commonwealth of Nations liczy pięćdziesięciu czterech członków: Wielka Brytania (z terytoriami zależnymi) oraz suwerenne monarchie i republiki (byłe kolonie, dominia i in. posiadłości brytyjskie), uznające monarchę brytyjskiego za głowę Wspólnoty Narodów. W ramach Wspólnoty prowadzone jest forum konsultacji i współpracy państw i społeczeństw w zakresie gospodarki, prawa, oświaty, nauki i techniki, wymiany informacji, sportu. Od $1965 \mathrm{r}$. stały sekretariat organizacji znajduje się w Londynie.

${ }^{12}$ T. R. Reddy, India's Policy in the United Nations, New Jersey 1968, s. 78.

${ }^{13}$ Ibidem.

${ }^{14}$ J. Nehru's Speeches, t. III (March 1953-August 1957), New Delhi 1958, s. 319.

${ }^{15}$ Ibidem, s. 80.

${ }^{16}$ Ibidem.
} 
rozgraniczającym walczące strony. $\mathrm{W}$ istocie miało to zabezpieczyć regiony zapalne przed wpływami wielkich mocarstw. Przede wszystkim jednak Indie chciały być postrzegane jako nowy ważny gracz polityczny występujący pod sztandarami ,pokojowego rozwiązywania konfliktów".

Należy zaznaczyć udział tego kraju w dwóch z najbardziej znaczących pokojowych misjach ONZ w tym czasie: UNEF (Unied Nations Emergency Force) — w celu stabilizacji regionu po kryzysie sueskim ${ }^{17}$ i ONUC (Unied Nations Operation in the Congo) - dla powstrzymania kryzysu kongijskiego trwającego w latach 1960-1962 ${ }^{18}$. Konflikt w Kongu jako pierwsza akcja militarna na terytorium ogarniętym wojną wewnętrzną — nabierał w tym aspekcie znaczenia prestiżowego. Uczestnictwo w tak znaczącej inicjatywie nobilitowało Indie do grona członków wielkiej społeczności międzynarodowej. Sympatią i poparciem rządu indyjskiego cieszył się również promotor tej formy rozwiązania konfliktów, sekretarz generalny ONZ i laureat Pokojowej Nagrody Nobla Dag Hjalmar Agne Carl Hammarskjöld ${ }^{19}$. Wyrazem tego poparcia była decyzja New Delhi o zasileniu kontyngentu wojskowego w Jugosławii oddziałami wycofanymi poprzednio z Afryki ${ }^{20}$. Indie udzielały wsparcia nie tylko na płaszczyźnie militarnej, ale stanowiły swoiste zaplecze psychologiczne i propagandowe operacji. Tak wyrazista postawa tego kraju - niekwestionowanego przywódcy Ruchu Państw Niezaangażowanych - legitymizowała decyzje organów ONZ i tworzyła parasol ochronny nad działalnością polityczną niepopularnego w wielu wpływowych kręgach sekretarza Hammarskjölda ${ }^{21}$.

Kolejnym ważnym aspektem działalności Indii było zaangażowanie w realizację programu rozbrojenia i kontroli zbrojeń. Powołanie tuż po zakończeniu drugiej wojny światowej ONZ stało się przyczynkiem do zainicjowania na jego forum wielu działań — w tym zakulisowych rozmów i oficjalnych negocjacji — niezbędnych dla rozwiązania tego kluczowego z punktu widzenia bezpieczeństwa światowego zagadnienia. Karta Narodów Zjednoczonych zakładająca konieczność przeprowadzenia rokowań rozbrojeniowych nie określiła metod i sposobów przyszłego rozbrojenia, wysuwając jedynie postulat ograniczenia zbrojeń jako warunku pokojowego rozwoju i współpracy międzynarodowej. W artykułach: 11, 26 i 47 sformułowano tylko ogólne zasady rozbrojenia i regulacji tej kwestii ${ }^{22}$. Dopiero w 1953 r. Zgromadzenie Ogólne ONZ uchwaliło rezolucję określającą poszczególne etapy

\footnotetext{
${ }^{17}$ Gotowość wysłania swych jednostek zgłosiły wówczas 124 państwa. Odrzucając ofertę państw z Bliskiego Wschodu oraz krajów mogących mieć szczególne interesy w regionie, zaaprobowano dziewięć ofert: Brazylii, Jugosławii, Danii, Finlandii, Indii, Indonezji, Kanady, Kolumbii, Norwegii i Szwecji. Liczebność sił UNEF wynosiła w przybliżeniu 6 tys. żołnierzy. Kontyngent indyjski liczył 957 żołnierzy i stanowił drugi pod względem liczebności. G. Ciechanowski, Operacje pokojowe ONZ w XX wieku, Torun 2013, s. 136, 137.

${ }^{18}$ Ibidem, s. 189-211.

19 Sekretarz generalny ONZ zginął w katastrofie lotniczej w Rodezji Północnej (dziś Zambia). Oficjalną przyczyną katastrofy miał być błąd pilota. Według innych teorii samolot miał zostać strącony. W latach dziewięćdziesiątych do spowodowania katastrofy przyznał się południowoafrykański tzw. Instytut Morski, będący przybudówką tajnych służb RPA — samolot z Hammarskjöldem miał być ostrzelany i strącony przez myśliwiec.

${ }^{20}$ Indyjski kontyngent brał udział w operacji ONUC od lipca 1960 r. do czerwca 1964 r. Trzon induskiego kontyngentu tworzyła 99 Brygada Piechoty. Ponadto Indie zaangażowały siły lotnicze, kompanię łączności i jednostkę poczty polowej. Ibidem, s. 206, 207.

${ }^{21}$ D. Hammarskjöld, Drogowskazy, Warszawa 1967.

${ }^{22}$ Karta Narodów Zjednoczonych, w: Prawo w stosunkach międzynarodowych. Wybór dokumentów, opr. S. Bieleń, Warszawa 1996.
} 
rozbrojenia ${ }^{23}$. Ponadto w oparciu o dokumenty ONZ wypracowano również zasady demilitaryzacji ${ }^{24}$. Stąd oczekiwania Indii, by w dobie zagrożenia poważnymi kryzysami międzynarodowymi ONZ mogła przejąć rolę kontrolera arsenału zbrojeniowego mocarstw. Jak czytamy w rezolucji Indyjskiego Kongresu Narodowego: „Osiągnięcie porozumienia — chociażby częściowego - i powstrzymanie wyścigu zbrojeń to najpilniejsze i najważniejsze zadanie chwili. Jednakże rozbrojenie może być osiągnięte jedynie poprzez porozumienie między wielkimi mocarstwami, które posiadają tę broń i które mogą wpłynąć na zmianę stanowiska na rzecz pokojowego rozwiązania konfliktów. Toteż Kongres apeluje do rządów na całym świecie, a w szczególności do mocarstw atomowych, by spełniły postulat opinii światowej i kontynuowały rokowania dla osiągnięcia porozumienia celem rozpoczęcia rozmów rozbrojeniowych, które obecnie stoją na martwym punkcie"25.

W ocenie działalności ONZ dokonanej przez premiera Nehru największe sukcesy odniesiono na polu powstrzymania zjawiska neokolonializmu i organizacji misji pokojowych. Program redukcji zbrojeń stał się nierealny w wyniku natężonego na niespotykaną dotąd skalę zjawiska wyścigu zbrojeń. Nehru był gorącym przeciwnikiem rozpowszechniania broni nuklearnej i apelował, by energia atomowa stanowiła jedynie źródło tak potrzebnej ludzkości energii. Jak bardzo zdawał sobie sprawę z destrukcyjnej roli wyścigu zbrojeń i rozpowszechniania broni atomowej, świadczą jego słowa wygłoszone podczas przemówienia parlamentarnego w 1957 r.: „Spójrzmy, na jakim świecie żyjemy. Egzystujemy na krawędzi zagłady. Broń atomowa i termojądrowa wytwarzana jest już na masową skalę. Przeprowadzane są kolejne próby termojądrowe, które prowokują sytuację kryzysowe i prowadzą świat na skraj wojny. Po raz pierwszy w historii świata stoimy w obliczu nowych możliwości i nowych zagrożeń. [...] Cały dotychczasowy dorobek ludzkości w jednej chwili może zostać zaprzepaszczony i starty z powierzchni ziemi. Doprowadzić może do tego broń masowej zagłady, która niszczy nie tylko gwałtownie, lecz także powoli poprzez przenikanie aż do szpiku kości w drodze procesu radioaktywności. Wszystkie nasze problemy i konflikty ideologiczne bledną i stają się niewiele znaczące wobec takiej perspektywy. Niebezpieczeństwo to może być powstrzymane jedynie dzięki cechom wypracowanym przez rodzaj ludzki — poszukiwaniu kompromisu i pokojowego rozstrzygania konfliktów" ${ }^{, 26}$.

Indyjski program rozbrojeniowy opracowany w połowie lat pięćdziesiątych koncentrował się w głównym stopniu na kompilacji zagadnień o charakterze politycznym, strategicznym i technologicznym. Indie stały na stanowisku, że wprowadzenie zakazu używania broni

\footnotetext{
${ }^{23}$ Są nimi: regulacja, ograniczenie, równoważna redukcja wszystkich sił zbrojnych i zbrojeń. W. Molendowski, Stosunki międzynarodowe, Wrocław 1999, s. 458.

${ }^{24}$ 1. Zasada powszechności ONZ zakłada objęcie porozumieniami rozbrojeniowymi jak największej liczby państw. 2. Zasada całkowitości dążyła z kolei do zupełnego eliminowania sił zbrojnych i zbrojeń, nie wliczając tutaj sił porządkowych. 3. Zasada równości dotyczyła każdego państwa rozpatrywanego na równych prawach w procesie rozbrojeniowym, bez ponoszenia szkód na każdym etapie rozbrojenia. 4. Zasada ścisłej kontroli procesu rozbrojeniowego narzucała kontrolę międzynarodową na wszystkie porozumienia rozbrojeniowe. 5. Zasada wiązania rozbrojenia $\mathrm{z}$ umacnianiem bezpieczeństwa zbiorowego zakładała, że rozbrojenie zgodnie z ideałami ONZ ma służyć stabilizacji sytuacji na świecie oraz utrzymania pokoju. Por. za: W. Multan, Porozumienia rozbrojeniowe po II wojnie światowej, Warszawa 1985, s. 7, 8.

${ }^{25}$ Rezolucja podjęta na 63 sesji Indyjskiego Kongresu Narodowego w styczniu 1958 r. Polityka zagraniczna Indii w latach 1956-1958. Dokumenty i bibliografia, oprac. B. Mrozek, Warszawa 1959, s. 77, 78.

${ }^{26}$ Przemówienie premiera Nehru w Parlamencie 21 III 1957 r. J. Nehru’s Speeches, t. III, op. cit., s. $362-364$.
} 
atomowej oznacza to samo co powszechne porozumienie rozbrojeniowe, któremu w imię bezpieczeństwa powinny przewodzić supermocarstwa, tworząc powszechny klimat pokoju dla całej społeczności międzynarodowej: „Prawdą jest, że program badań jądrowych był łączony z szerszym problemem ogólnego rozbrojenia i obie te sprawy są do pewnego stopnia powiązane. Jednakże ciągle byliśmy zdania, że postęp w dziedzinie ogólnego rozbrojenia jest możliwy jedynie w drodze stopniowych ustępstw i pierwszy krok w tym kierunku winien być związany z zaprzestaniem prowadzenia doświadczeń nad bronią termojądrową. Wierzymy, że nastąpią dalsze kroki i wszystkie mocarstwa zainteresowane uzgodnią bezwarunkowy zakaz produkcji i stosowania wszelkich typów uzbrojenia termojądrowego. Jeśli zakaz ten ma być efektywny, to musimy oprócz wzajemnego zaufania wypracować formę kontroli przyjętego programu" ${ }^{27}$. Jednak w praktyce indyjskie postulaty wobec tak złożonego problemu jak zagadnienie inspekcji i kontroli arsenału atomowego mocarstw okazały się głosem wołającego na puszczy i ograniczyły się jedynie do potępienia tego rodzaju broni.

Zdaniem premiera Indii $\mathrm{w}$ epoce gwałtownego postępu technologicznego idea walki z proliferacją broni jądrowej — bez zapewnienia bezpieczeństwa międzynarodowego — okaże się nierealna. Skomplikowana sytuacja polityczna i niepohamowany rozwój technologiczny mógł uwikłać powojenny świat w konflikt o wiele groźniejszy niż te, które miały miejsce w przeszłości. Indie podkreślały, że jako państwo deklarujące w polityce zagranicznej zasadę „potępienia wszelkich wojen”, z pewnością poprą propozycje i ustalenia wielkich mocarstw dotyczące powołania stref bezatomowych i opowiedzą się za zastosowaniem atomu jako alternatywnego źródła energii. Takie stanowisko obowiązywało aż chwili, kiedy stało się oczywiste, że USA będą budować sojusz z państwami Azji Południowejej ${ }^{28}$.

Jeszcze w połowie lat pięćdziesiątych rząd indyjski podtrzymywał swe nieugięte stanowisko wobec zakazu przeprowadzania prób termojądrowych. 2 IV 1954 r. premier Nehru w specjalnych notach skierowanych do przywódców USA i ZSRS - wystąpił z inicjatywą wprowadzenia takiego zakazu. Wprawdzie porozumienie dotyczące zahamowania prób nuklearnych podpisano dopiero w 1963 r., jednak było ono bardziej restrykcyjne od propozycji indyjskiej $^{29}$. Indie pozbawione w tym czasie potencjału nuklearnego nie były naturalnie sygnatariuszami układu, ale odniosły się do tego porozumienia pozytywnie — jako jedno z pierwszych państw zapewniły o przestrzeganiu zasad wynikających z układu.

Zagadnienie nieproliferacji broni jądrowej rozpatrywane na arenie międzynarodowej, szczególnie w latach sześćdziesiątych, stało się przedmiotem zainteresowania dyplomacji indyjskiej jeszcze za życia Jawaharlala Nehru. Troszcząc się już o realizację rodzimego programu atomowego, Indie naciskały na wypracowanie takich ustaleń, które będą zawierały określenia dotyczące wykorzystania energii atomowej tylko w celach pokojowych ${ }^{30}$. Nowe Delhi dążyło do wprowadzenia zakazu rozprzestrzeniania broni jądrowej przede wszystkim

${ }^{27}$ Cyt za: Polityka zagraniczna Indii, s. 75, 76.

${ }^{28}$ Ch. H. Heimsath, S. Mansingh, A Diplomatic History of Modern India, Bombaj 1971, s. 355-358.

${ }^{29}$ Porozumienie podpisały tylko USA, ZSRS i Wielka Brytania. Układ o zakazie prób z bronią jądrową w atmosferze, przestrzeni kosmicznej i pod powierzchnią wody. P. Calvocoressi, Polityka międzynarodowa 1945-2000, Warszawa 2000, s. 52.

${ }^{30}$ Premier Nehru uważał program nuklearny za niezbędny i konieczny do przezwyciężenia słabości przemysłowej Indii. Tuż po odzyskaniu niepodległości została powołana komisja energii atomowej mająca za zadanie rozpoczęcie badań nad technologią nuklearną. Indyjski program atomowy zakładał zastosowanie tego rodzaju energii jedynie w celach pokojowych. Pragnienie i konieczność wprowadzenia Indii na drogę rozwoju ekonomicznego determinowały indyjskie spojrzenie na kwestię broni nuklearnej na arenie międzynarodowej. 
w odniesieniu do potencjału supermocarstw ${ }^{31}$. Tak nieprzejednane stanowisko było powodem marginalizowania koncepcji Nehru przez mocarstwa atomowe. Co więcej, „krucjata antyproliferacyjna" wpłynęła na usztywnienie niechętnego wobec Indii stanowiska również w kwestii innych propozycji, w tym rozwiązania problemu głodu i ubóstwa w krajach Trzeciego Świata.

Dominacja modelu kształtowania relacji międzynarodowych przez układ dwublokowy determinowała rząd indyjski do kreowania nowych alternatywnych rozwiązań w polityce zagranicznej.

Jednym z nich była idea pokojowego współistnienia oparta na pięciu zasadach tzw. Pancza Szila, zawartych w preambule chińsko-indyjskiego traktatu w sprawie Tybetu z 29 IV 1954 r. Przemawiając 5 XI 1956 r. na sesji Konferencji Generalnej Organizacji Narodów Zjednoczonych do Spraw Oświaty, Nauki i Kultury (UNESCO) w stolicy Indii, Nehru wymienił zasady, którymi — jego zdaniem — powinny kierować się w stosunkach międzynarodowych państwa członkowskie ONZ:

1. Wzajemne poszanowanie dla suwerenności i integralności terytorialnej.

2. Wyrzeczenie się agresji we wzajemnych stosunkach.

3. Nieingerencja w sprawy wewnętrzne.

4. Równorzędne i obopólnie korzystne stosunki.

5. Pokojowe współistnienie.

Swoje stanowisko podtrzymał 3 X 1960 r. podczas wystąpienia na Zgromadzeniu Ogólnym ONZ: „Nasze gorące pragnienie rozwoju ekonomicznego, a w konsekwencji podwyższenia standardu życia jest celem setki milionów obywateli. Jednakże jest jeszcze coś, co uważamy za bardzo istotne i czego pragniemy — to pokój. Bez pokoju nasze wszystkie marzenia zostaną zmienione w pył. Główny celem ONZ jest budowa świata bez wojny, świata opartego na współpracy narodów i ludzi. Nie chodzi tu tylko o sytuację, w której konflikty powstrzymywane są dzięki wypracowanej równowadze sił. Zależy nam, by główne przyczyny wojny były usuwane zawczasu, a społeczeństwa i narody współpracowały na rzecz rozwiązywania konfliktów"32. Premier Indii zaapelował również, by rok 1961 ogłosić Międzynarodowym Rokiem Współpracy (International Cooperation Year).

Wprawdzie przywódca Indii nigdy nie podawał pod wątpliwość celowości istnienia ONZ, jednak negatywne opinie dotyczące działalności tej organizacji pojawiały się w niektórych indyjskich kołach politycznych. Krytykowano ONZ za bezsilność i nieskuteczne działania w konflikcie m.in. o Kaszmir i Tajwan, a także za brak rozwiązań problemu rasizmu w Afryce Południowej. Równocześnie podkreślano zasługi w zapobieganiu i przezwyciężaniu głodu, ubóstwa i klęsk żywiołowych. Należy podkreślić przy tym, że relacje na linii New Delhi-Nowy Jork postrzegane były jako oderwane od rzeczywistości i przesadnie idealistycz$\mathrm{ne}^{33}$. W wystąpieniach indyjskich dyplomatów na forum międzynarodowym podkreślano, że ONZ ,jest jedyną organizacją w historii, która chroni świat przed globalnym konfliktem". Nehru był przekonany, że to rywalizacja zimnowojenna nie pozwala tej organizacji skutecznie przeciwdziałać lokalnym wojnom. By poskromić zakusy mocarstw, Narody Zjednoczone powinny jego zdaniem przejąć rządy nad światem: „ONZ pomimo swoich słabości jest instytucją niezwykle potrzebną. Należy tą organizację bezwzględnie popierać. ONZ powinno stworzyć rząd światowy, dbający o porządek i kierujący wszystkimi dziedzinami życia"34.

\footnotetext{
31 A. P. Rana, op. cit., s. 235.

32 Zbiór dokumentów, PISM, nr 10, 1960, s. 1740.

33 A. P. Rana, op. cit., s. 236.

34 Przemówienie Nehru na Zgromadzeniu Konstytucyjnym 8 III 1948 r. w Nowym Delhi. J. Nehru, Independence and After. A Collection of Speeches (1946-1949), New York 1950, s. 214.
} 
Dostrzegał przy tym poważne niebezpieczeństwo zaszczepienia klimatu wrogości również w łonie ONZ. By nie doprowadzić do instrumentalnego wykorzystania Organizacji w dwublokowej rywalizacji mocarstw, Indie opowiadały się za utrzymaniem prawa weta w Radzie Bezpieczeństwa. Miało to zabezpieczać ONZ przed zakusami narzucenia dominacji przez jedną ze stron konfliktu zimnowojennego, a także ograniczać możliwość nadużywania środków militarnych ${ }^{35}$.

W kolejnym przemówieniu w sierpniu 1952 r. Nehru wyraził przekonanie o konieczności kształtowania porządku światowego w duchu Karty ONZ, jak również rozszerzania tego systemu na nowe obszary: „Będąc obiektywnym, a w związku z tym również krytycznym w odniesieniu do działalności ONZ, zauważam, że odchodzi od Karty i od tego, co było wcześniej ustalone. Wierzyłem i wierzę nadal, że ONZ mimo wielu usterek, mimo głębokich podziałów, jest fundamentalną instytucją w strukturze światowego porządku [...]"36.

W wystąpieniach Jawaharlala Nehru nie brakowało apeli o utrzymanie jedności ONZ: „Ta wspaniała organizacja powołana do budowy pokoju zajmuje się dzisiaj sponsorowaniem wojny. Nie chcę nikogo obwiniać, ale próbuję tylko przeanalizować sytuację najbardziej obiektywnie, jak potrafię. Czy jest możliwe, że świat nie dorósł lub jest niezdolny do powołania pokojowej organizacji międzynarodowej? Wszyscy mówimy o zjednoczonym świecie, wielu z nas jest rzecznikami idei federalizmu. Jednocześnie sami doprowadzamy do odwrotnego efektu. Czy jest możliwa współpraca państw całkowicie różniących się pod względem ekonomicznym i politycznym? Jestem przekonany, że to możliwe, i co więcej, nie widzę powodu, dlaczego współpraca ta nie małaby być skuteczna. Kiedy powstało ONZ, państwa takie jak USA i ZSRS współpracowały ze sobą. Nie widzę powodu, dlaczego nie mogłyby one nadal funkcjonować w ten sposób i jednocześnie powstrzymywać się przed nakłanianiem do występowania przeciwko sobie innych państw"37.

Obawy wyrażane przez przywódcę Indii znajdowały potwierdzenie w faktach. Rywalizacja supermocarstw uniemożliwiła rozwiązanie konfliktów na Bliskim Wschodzie, zaogniał się spór o Kaszmirze. Indyjczyków niepokoiła zwłaszcza sytuacja sąsiadującego z Indiami Kaszmiru. Ożywiona dyskusja wśród indyjskich polityków sprowadzała się do sporów o celowość dalszego zaangażowania w działalność ONZ. Nehru wielokrotnie wypowiadał się w tej kwestii, między innymi w parlamencie, twierdząc, że sytuacja polityczna Kaszmiru nie może wpłynąć na decyzję rządu odnośnie do zawieszenia członkostwa w ONZ. Zapewniał jednocześnie o potrzebie obrony interesu narodowego: „Szanujemy dorobek i cele ONZ oraz innych organizacji międzynarodowych działających na rzecz pokojowego rozwiązywania konfliktów. Słuszne jest, że powinniśmy pozostać członkami ONZ — pomimo wszystko. Jednocześnie nikogo nie powinno dziwić, że czynimy tak wiele w interesie naszej ludności w Kaszmirze. Nikt nie może narzucać nam niehonorowych rozwiązań. Zdecydowaliśmy się oczekiwać na werdykt Rady Bezpieczeństwa tak długo, jak będzie trzeba. Droga do pokoju jest zawsze korzystniejsza chociaż jest ona bardzo długa. Wojna nie jest tu sposobem na wszystko i nic nie rozwiązuje"38.

Jednocześnie Nehru usiłuje przekonać polityków indyjskich o bezcelowości dyskusji nad opuszczeniem szeregu państw członkowskich: „Szanowni parlamentarzyści, pewne sugestie odnoszące się do pomysłu opuszczenia ONZ są dla mnie frustrujące. Z całym szacunkiem -

\footnotetext{
${ }^{35}$ W. Range, Jawaherlal Nehru's World View. A Theory of International Relations, University of Georgia Press, Athens 1961, s. 108-110.

${ }^{36}$ J. Nehru's Speeches (1949-1953), New Delhi 1954, s. 349.

37 Przemówienie J. Nehru w parlamencie 18 II 1953 r., ibidem, s. 246, 247.

38 Przemówienie J. Nehru w parlamencie 12 II 1952 r., ibidem, s. 207.
} 
taka postawa wykazuje waszą dużą niedojrzałość. Po pierwsze, nie powinniśmy uciekać przed tego typu problemami. ONZ pomimo swych niedoskonałości i błędów jest znaczącą organizacją. Daje nadzieję, zabiega o pokój i tylko niektóre państwa w sposób obłudny próbują zniszczyć jej struktury. Jeśli te państwa to robią, nie mam wątpliwości, że ucierpią na tym jeszcze bardziej. My nie możemy izolować się od świata, gdyż on przenika do nas w każdej sferze życia. Wielu z nas uważa, że izolacjonizm to naturalny stan naszych umysłów. Żyjemy w podziałach systemu kastowego, który w takiej formie nie występuje w żadnym kraju. Ta mentalność — w czasach, gdy reszta świata przeżywała swój rozwój — bardzo nam szkodzi’39.

Indie starały się zaznaczyć swoją pozycje również w strukturze organizacyjnej ONZ. Państwo to kilkakrotnie dostąpiło honoru bycia niestałym członkiem Rady Bezpieczeństwa — po raz pierwszy od 1 I 1950 r. do 31 XII $1951 \mathrm{r}^{40}$ Politycy indyjscy pełnili w organach ONZ często kluczowe funkcje. Warto wspomnieć Vijayę Lakshmi Pandit ${ }^{41}$, która zapisała się w historii jako pierwsza kobieta - przewodnicząca Zgromadzenia Ogólnego ONZ (VIII sesja w 1953 r.), a także Ramaswami Mudaliara ${ }^{42}$ — pierwszego przewodniczącego Rady Społeczno-Gospodarczej (wybranego podczas sesji w Church House London 26 I 1946 r.). Za jego prezydentury w lutym 1946 r. Rada Społeczno-Gospodarcza podjęła uchwałę wzywającą do powołania Międzynarodowej Konferencji Zdrowia. Od czerwca 1946 r. polityk ten przewodniczył Międzynarodowej Konferencji Zdrowia, na której została powołana Światowa Organizacja Zdrowia (WHO).

Aktywiści indyjscy w osobach Rajkumari Amrit Kaur ${ }^{43}$ i Maulana Azada ${ }^{44}$ byli aktywnie zaangażowani w prace organizacyjne i działalność UNESCO. Ponadto Indie zaznaczyły swą obecność w Międzynarodowym Trybunale Sprawiedliwości w Hadze, którego sędzią był wybitny prawnik, hindus Benegal N. Rau ${ }^{45}$. Należy wspomnieć, że przed wyborami do składu sędziowskiego Trybunału rozważano jego kandydaturę na stanowisko sekretarza generalnego. Indie były również jednym z osiemnastu członków Komisji Rozbrojeniowej ${ }^{46}$.

\footnotetext{
${ }^{39}$ Przemówienie J. Nehru w Parlamencie, New Delhi, 17 IX 1953 r., ibidem, s. 243, 244.

${ }^{40}$ Po raz kolejny Indie były członkiem niestałym w Radzie Bezpieczeństwa w latach 1967-1968, 1972-1973 i 1977-1978. H. M. Verma, op. cit., s. 161.

${ }^{41}$ Vijaya Lakshmi Pandit (1900-1990), dyplomata, polityk, siostra premiera J. Nehru. Działaczka indyjskiego ruchu narodowego. Delegat do ONZ w latach 1946 i 1948. Była pierwszą kobietą, przewodniczącą Zgromadzenia Narodowego. W latach 1947-1949 ambasador Indii w Moskwie, następnie w Meksyku (1949-1951), w Waszyngtonie (1952-1955), Hiszpanii (1958-1961). W 1979 r. została mianowana na przedstawiciela Komisji Praw Człowieka ONZ. Autorka książek The Evolution of India (1958) i The Scope of Happiness. Personal Memoirs (1979).

${ }^{42}$ Ramaswami Mudaliar (1887-1976), prawnik, indyjski polityk i dyplomata. Delegat Indii do ONZ na konferencji w San Francisco, podczas której stał na czele komitetu omawiającego problemy gospodarcze i społeczne. W 1946 r. powrócił do Indii.

${ }^{43}$ Rajkumari Amrit Kaur (1889-1964), działaczka niepodległościowa, współpracowała z Gandhim. W rządzie J. Nehru stała na czele Ministerstwa Zdrowia. Działaczka na rzecz praw kobiet. Była członkiem indyjskiej delegacji do UNESCO a także Rady Powierniczej.

${ }^{44}$ Maulana Azad (1888-1958), urodzony w Mekkce członek Indyjskiego Kongresu Narodowego. Jako muzułmanin wierzył w jedność hindusko-muzułmańską. W rządzie Nehru był ministrem edukacji. W 1956 r. pełnił funkcję prezesa UNESCO konferencji genewskiej w Nowym Delhi.

${ }^{45}$ Benegal N. Rau (1887-1953) urzędnik indyjski, prawnik, dyplomata i polityk. Odegrał kluczową rolę w opracowaniu Konstytucji Indii, a także Birmy z 1947 r. Był przedstawicielem Indii w Radzie Bezpieczeństwa ONZ w latach 1950-1952. Jako przedstawiciel Indii w Radzie Bezpieczeństwa popierał pomoc zbrojną dla Korei Południowej. Po zawieszeniu broni był członkiem UNCMAC.

${ }^{46}$ Na XVI sesji Zgromadzenia Ogólnego ONZ w 1961 r. został powołany Komitet Rozbrojeniowy 18 Państw, w tym ośmiu neutralnych (Brazylia, Birma, Indie, Meksyk, Nigeria, Szwecja, Etiopia, Zjed-
} 
Oprócz aktywnego uczestnictwa w strukturach ONZ Indie wspierały także wszelkie wysiłki tej organizacji mające na celu rzeczywiste utrzymanie pokoju. Ponad 85 tys. żołnierzy indyjskich, obserwatorów wojskowych i sił policyjnych brało udział w czterdziestu dwóch misjach pod sztandarem ONZ. Państwo indyjskie wysłało misję medyczną do Korei i wojska pokojowe do Gazy oraz Konga. Wysokiej rangi wojskowi Indian Army pełnili funkcję dowódców Emergency Forces w wielu punktach zapalnych na świecie. 116 indyjskich żołnierzy poniosło na misjach śmierć, za co zostali uhonorowani medalem Dag Hammarskjöld ${ }^{47}$.

Aktywność dyplomacji indyjskiej na forum ONZ dotyczyła nie tylko nadrzędnego celu podkreślenia roli subkontynentu indyjskiego na arenie międzynarodowej i rozpowszechniania ideologii niezaangażowania. Zabiegano również o możliwość przedstawienia sytuacji krajów Trzeciego Świata i zapewnienia pomocy gospodarczej dla państw postkolonialnych. W przemówieniu na sesji Zgromadzenia Ogólnego w Paryżu w 1948 r. premier Nehru dał wyraz przywiązania do współpracy ekonomicznej powojennego świata, twierdząc, że jest ona tak samo konieczna jak współpraca polityczna: „Człowiek nie może funkcjonować z dala od polityki i ekonomii. Stąd też idea powołania UNESCO — instytucji niezbędnej dla ludzkiej egzystencji i rozwoju. Podczas gdy Zgromadzenie Ogólne ONZ reprezentuję polityczną stronę światowej społeczności, UNESCO ma wyznaczone zadanie reprezentowania szerszej stronę życia ludzkiego — rzeczywistej konsystencji światowej społeczności [...]",48.

Dzięki wsparciu ONZ znacząca pomoc ekonomiczna trafiła również do Indii. Około 200 ekspertów z ramienia tej instytucji wspierało reformy gospodarcze w zakresie rolnictwa, infrastruktury, edukacji zdrowia i technologii. Pozyskiwano subwencje z oenzetowskiego Programu Rozwoju i Odbudowy — od 1959 r. do połowy lat siedemdziesiątych ponad pięćdziesiąt projektów pomocowych dla Indii pochodziło z środków $\mathrm{ONZ}^{49}$.

Rola, jaką odegrał premier Republiki Indii w krzewieniu wśród rodaków idei współpracy międzynarodowej, pokojowego rozwiązywania sporów i obrony praw człowieka jest nieoceniona. Indie pamiętają i szczycą się pamięcią swojego przywódcy ${ }^{50}$. Nehru — wybitny mąż stanu swoich czasów był postacią rozpoznawaną i szanowaną w każdym bez mała zakątku naszego globu. Przemówienia premiera Republiki Indii na Zgromadzeniu Ogólnym ONZ (trzykrotnie na sesjach w 1948, 1956, 1960 roku) cieszyły się ogromnym zainteresowaniem opinii międzynarodowej. Nehru pełnił rolę gospodarza na Międzynarodowej Konferencji Generalnej UNESCO, która odbyła się w 1956 r. w Nowym Delhi: ,[...] Nazywam to wspaniałe zgromadzenie - jak czytamy w przemówieniu inauguracyjnym — esencją światowej społeczności. Problemy przed jakimi stajemy są liczne, komplikują sytuację międzynaro-

noczona Republika Arabska), z siedzibą w Genewie. Od 1962 r. działający jako Konferencja Komitetu Rozbrojeniowego 18 Państw. W latach 1969-1978 jego skład powiększono do czterdziestu państw, w tym gronie znalazły się wszystkie państwa dysponujące bronią jądrową. Komitet nie jest organem ONZ, ale utrzymuje z nią ścisłe kontakty. Co roku przedkłada Zgromadzeniu Ogólnemu sprawozdania ze swojej działalności i otrzymuje odeń wnioski i zalecenia dotyczące jego pracy. Prace tego organu doprowadziły do podpisania kilku ważnych układów dotyczących zakazu nuklearyzacji w środowisku człowieka (atmosfera ziemska, przestrzeń kosmiczna, dna mórz i oceanów) w celach wojskowych, ograniczenia swobody przeprowadzania doświadczalnych wybuchów jądrowych, do zawarcia Układu o nieproliferacji broni jądrowej. P. Calvocoressi, op. cit., s. 51.

${ }^{47}$ A. Sinha, M. Mohta, op.cit., s. 201.

${ }^{48}$ Wystąpienie Nehru na Zgromadzeniu Ogólnym w Paryżu 3 XI 1948 r. J. Nehru, Independence and After, op. cit., s. 322.

${ }^{49}$ H.M. Verma, op. cit., s. 162.

${ }^{50}$ Imię J. Nehru nosi w Indiach wiele instytucji użytku publicznego, programów rządowych, fundacji, uczelni, instytucji naukowo-badawczych, ośrodków kulturalnych. 
dową i często poróżniają nas. Ale nie możemy zaakceptować rozwiązań, które dewaluują wartości moralne jakie wyznajemy. Jeśli takie zagrożenie się pojawi będę apelował do Was szanowni delegaci, byście — przed przystąpieniem do stołu gry — zważyli skutki waszych działań, skutki odrzucenia ideałów jakie wyznajemy. [...] Indie nie narzucają swego władztwa żadnemu krajowi. Nie chowamy w sobie nienawiści. Jesteśmy inspirowani nurtem naszego wspaniałego lidera Mahatmy Gandhiego i jego drogą do pokoju. Chcemy żyć w przyjaźni $\mathrm{z}$ całym światem $[\ldots]^{, 51}$.

\section{The Role of India in the United Nations Organisation according to the Political Conception of Jawaharlal Nehru}

India's accession to the international system which is the UN stemmed from the conviction that it is an organization that in the postwar world shaped international relations based on the principle of political and economic cooperation and safeguard the peace. India's membership in the United Nations gave opportunities for the dissemination of political ideology and beliefs regarding aspects such as anti-colonialism, disarmament, peacekeeping. This created the opportunity to play a significant role for India in world politics. Hence, since accession to the UN India very actively engaged in the work and activities for the organization. India offered their services to mediate between the parties to the conflict, working in support of the independence movement and for the avoidance of violence between states, also tried to mark their positions within the UN. The presence of India in the United Nations and the active involvement of the various field activities of this organization is not only an opportunity to indicate their role in the international arena and spread an ideology of non-alignment, but also the opportunity to speak in the interests of the Third World and to winning economic aid to post-colonial states.

Translated by Joanna Maj

${ }^{51}$ Przemówienie na inauguracji 10 sesji UNESCO w New Delhi XI 1956 r. J. Nehru’s Speeches, t. III, s. $500,503$. 